\title{
An empirical study of innovation-performance linkage in the paper industry
}

\author{
Parveen Farooquie*, Abdul Gani, Arsalanullah K Zuberi and Imran Hashmi
}

\begin{abstract}
To enter new markets and remain competitive in the existing markets, companies need to shift their focus from traditional means and ways to some innovative approaches. Though the paper industry in India has improved remarkably on its technological and environmental issues, yet it shows a low rate of innovation. The present paper attempts to review the industry in the perspective of technological innovations and investigates empirically the role of innovations in performance improvement and pollution control. Multivariate analysis of variance and discriminant function analysis are applied for data processing. The findings reveal that the mean scores on the factors, such as sales, quality, and flexibility, are higher for the good innovators than those for the poor innovators. Conversely, the factors which are likely to be reduced as a result of innovations, such as time, cost, emissions, and disposal of waste, have shown higher means for the poor innovators.
\end{abstract}

Keywords: Discriminant function analysis, Paper industry, Performance, Multivariate analysis of variance, Technological innovation

\section{Background}

The basic philosophy behind any business organization is to produce the intended products and sell them to earn profit and satisfy customer requirements. Profitability and other such targets can be achieved, maintained, and excelled only when the performance is regularly measured and monitored. Organizations design their own systems of performance evaluation depending on the environment they work in and the nature of their operations. According to Fitzgerald et al. (1991), the framework for measuring the performance of any organization should integrate the measures that relate to results, such as competitiveness, and those that focus on the determinants of the results, such as quality and innovation. To enter new markets and remain competitive in the existing markets, companies need to shift their focus from traditional means and ways to some innovative approaches. Various studies have been reported in the literature to draw the attention of academicians and professionals towards the role of technological and nontechnological innovations in performance improvement. According to the Oslo Manual, innovation means

\footnotetext{
* Correspondence: parveenfarooquie@yahoo.com

Department of Mechanical Engineering, Aligarh Muslim University (AMU), Aligarh, India
}

implementation of a new or significantly improved product, process, marketing method, or organizational method in business practices and organizations. Innovations in technical specifications, materials, and characteristics, of a product are said to be product innovation, whereas innovations pertaining to technique, process, and equipment are known as process innovation. The product and process types of innovations are together known as technological innovations and abbreviated as TPP. The non-technological category includes innovations related to marketing and organizational practices (OECD 2005).

With an annual output of over 6 million tons and an estimated turnover of US\$3,400 million, the Indian paper industry is continuously progressing towards a projected demand of 8 million tons of paper in the year 2010 and 13 million tones by 2020 (Paper industry in India 2009). Though the industry has improved remarkably on its technological and environmental issues, yet it shows a low rate of innovation. Challenges such as pulp quality variation, high consumption of water and energy, raw material cleaning and storage, flexibility to reduce the multiplicity of paper grades, use of forest resources, water and air pollution, and production of solid waste are still alive. \\ Springer}


Paper looks simple compared to, for example, computers and mobile phones, but a lot of technology is involved in the pulp and paper process. Also, as technology develops, paper can become much more than what it is today (Karlsson 2009). Karlsson (2009) quotes a professor of Fibre and Cellulose Technology at Åbo Akademi University, 'It's difficult to say why the industry isn't that attractive any more. Perhaps young people find paper to be something old-fashioned and boring and think that its development is complete, but this is not the case at all. There is still a lot to explore, and we are in an exciting phase when innovative thinking is needed to take the industry forward. Now, more than ever, we need talented people.'

The present paper attempts to review the industry in the perspective of technological innovations. The study investigates empirically how such innovations contribute in performance improvement and pollution control.

\section{Literature review}

Neely et al. (1995) have defined performance measurement as quantification of effectiveness and efficiency. They have discussed important performance measures relating to cost, quality, time, and flexibility. Since there are numerous dimensions of each one of these performance determinants, researchers have applied them differently. Kaplan and Norton (1992) have a balanced scorecard approach of performance measurement which suggests four perspectives of any organization to be considered - financial (e.g., sales), internal business (e.g., flexibility), customer (e.g., quality, cost, and time), and innovation and learning (e.g., ability to innovate). Gomes et al. (2006) have identified 25 performance factors in manufacturing. They categorized them into six dimensions through factor analysis - operational responsiveness, market-related, costumer-driven, quality orientation, employees' involvement, working conditions, and innovation.

Innovation has emerged as a key to success for companies which want to remain competitive in the market or enter a new market. Researchers have been studying various issues pertaining to innovations in different industries such as pattern of innovation (Pavitt 1984; Freel 2005), determinants and measures of innovation (Wan et al. 2005; De Jong and Vermeulen 2006), process of innovation (Nieto 2004), manufacturing strategies and innovation performance (Prajogo et al. 2007), and impact of innovation on companies' performance (Lin and Chen 2007; Mansury and Love 2008). Manufacturing sector has particularly witnessed a positive relationship between firm innovation and its performance (Loof and Heshmati 2002). The study by Lin and Chen (2007) is about the role of innovation in performance gain in the context of small and medium enterprises (SMEs) in Taiwan. Their findings include that the majority of the sample companies have done innovation in some form or the other. They also conclude that two types of innovation - technological and marketing - were more prominent than other types. Though the effect of innovation activities has been positive on the overall performance, yet they do not contribute strongly to the company sales. Mansury and Love (2008) have conducted a study in the service sector in the USA. Their findings also indicate a positive relationship between innovation and performance with productivity as an exception.

\section{Results and discussion}

The responding companies consist of manufacturers of paper, suppliers of raw material or equipments, and those which may be categorized as both supplier as well as manufacturer. The sample companies have been labeled as small or large based on the number of their full-time permanent employees. Companies with 100 or less employees are called small, and the ones with more than 100 are referred to as large.

\section{Company innovativeness}

Compatible with the Oslo Manual of OECD (2005) and based on the evidence from the literature (Wan et al. 2005; De Jong and Vermeulen 2006), a set of six questions was developed to measure the magnitude and novelty of innovation commercialized by the firms. The questions ask about the number of technologically new or improved processes or products (raw material in case of suppliers) implemented or introduced by a firm first time to itself or to the industry during the last three years (April 2006 to March 2009).

For computation convenience, an equal weightage has been assigned to each item, and hence, the simple average of the scores of a company on these six items represents its technological innovativeness (INNO). Such scores have ranged between 0.33 and 5.83 with a mean of 3.78 . For further analysis, the companies with average score of 3.78 or less are designated as poor innovators (denoted by numeral 1 ); those with higher values, as good innovators (denoted by numeral 2). As shown in Figure 1, around 62\% of the manufacturers have been assessed as good innovators, whereas there are more poor innovators (55\%) in the others category. (Those who are suppliers-cum-manufacturers have been grouped with suppliers to form a single category, others). It could be understood that due to their nature of operations, the manufacturers might have scored higher than the suppliers on product and process innovation. This appears as one strong reason for them to outperform the others on the overall innovativeness.

\section{Technological innovation and performance}

Another set of questions measures the effect of innovations on company sales (SALE) and on other important 
determinants of company performance such as production time (TIME), production cost (COST), production flexibility (FLEX), and production quality (QUAL) (Neely et al. 1995; Kaplan and Norton 1992). Since the study deals with the paper industry, environmental factors such as emission of hazardous fumes (EMSN) and disposal of solid waste (DISP) are also included in the study as another two important (dependent) variables. This is evidenced from the literature that researchers have examined innovation as a dependent (Wan et al. 2005) as well as an independent variable (Lin and Chen 2007; Mansury and Love 2008). The present paper studies innovation as an independent variable.

Respondents were requested to report the effect of technological innovations, which they have introduced during the mentioned period of three years, on these performance parameters. A five-point Likert scale (Sawang 2006) ranging from improved significantly through improved moderately, no effect, worsened moderately to worsened significantly was proposed to them for this purpose. Bivariate correlation analysis is then run on the data obtained on company innovativeness.

Table 1 shows that whether performance is in the form of outputs (such as sales), production factors (such as production time, cost, flexibility, and quality) or environmental hazards (such as emissions and disposal of wastes), innovativeness is likely to have its impact on it. Except for production flexibility, all performance indicators have a significant correlation with the company's innovativeness. Sales, the most commonly used measure of performance, shows a highly significant positive relationship with innovative-ness. The ability of a company

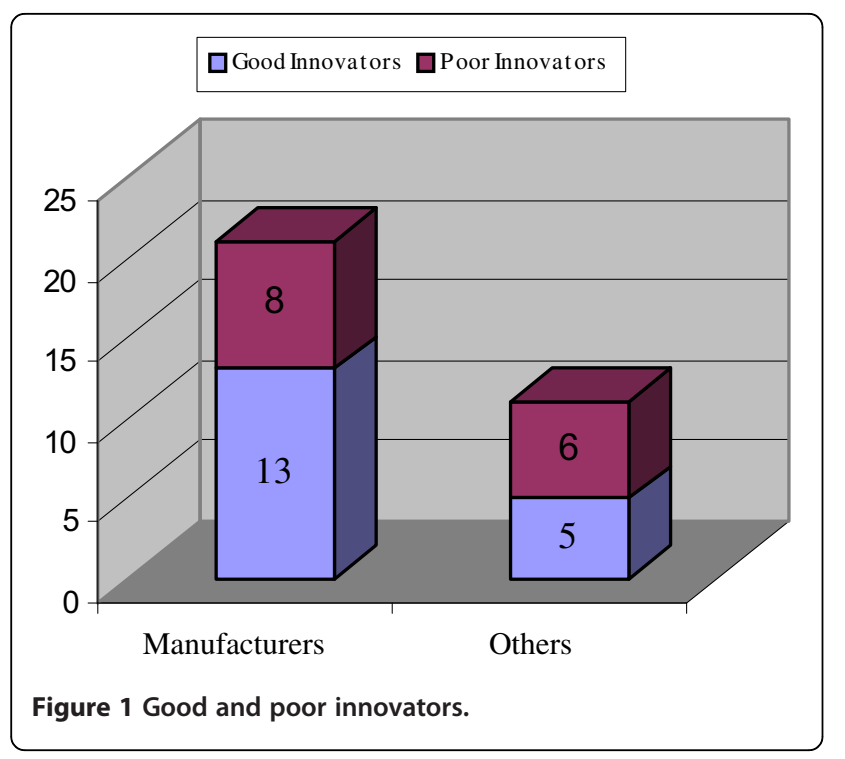

to quickly incorporate the changes required in volume and deign (flexibility) and improve the quality has been found positively linked with how innovative the company is. However, the strength of relationship between innovativeness and flexibility is not significant. Since greater flexibility is more a factor of process innovation, this insignificant correlation may be explained by examining the companies' scores on process and product innovations separately. This argument is also supported by the literature, which reports that considering product and process innovation together or separately does influence the effect of innovation on performance (Michie and Sheehan 2003). The correlation coefficients also indicate that the greater the company innovativeness, the lower is the production time, cost, emission, and waste. This may be inferred that innovative companies not only perform better in competitive terms, but also are less harmful to the environment.

To further investigate the relationship between innovation and performance, MANOVA is carried out with company innovativeness as the predictor variable, whereas changes occurred due to innovation in the sales, time, cost, quality, flexibility, emissions, and waste production as dependent variables. The results are shown in Tables 2 and 3.

Descriptive statistics indicate that the mean scores on the factors such as sales, quality, and flexibility are higher for the good innovators than those for the poor innovators. Conversely, the factors which are likely to be reduced as a result of innovations, such as time, cost, emissions, and disposal of waste, have shown higher means for the poor innovators. This can also be observed from the standard deviation column that good innovators have been more consistent than their poor counterparts, except in cases of quality and flexibility, where wider dispersions are reported for the good innovators. The overall situation signals that innovation is likely to affect all variables positively.

The Box's test of equality of covariance matrices is conducted to validate the assumption of homogeneity before proceeding further. The result (Box's $M=36.229$; $p=.530$ ) suggests that the assumption is valid, and hence, the multivariate tests (Table 3 ) are reliable (Field 2005). The significance column and INNO row of Table 3 indicates that innovations have a significant effect on performance. However, the results do not tell anything in detail. To investigate this effect with reference to the individual variables and their combinations, DFA is applied. Since there are only two groups (good innovators and poor innovators) involved in this analysis, there has to be a single discriminant function variate. The initial outcome of the DFA reveals that this variate is significant (Wilk's lamda $=.361 ; p=.000$ ). Finally, the structure 
Table 1 Correlation matrix

\begin{tabular}{|c|c|c|c|c|c|c|c|c|c|}
\hline Factors & & INNO & TIME & COST & DISP & EMSN & SALE & FLEX & QUAL \\
\hline \multirow[t]{3}{*}{$\overline{I N N O}$} & Correlation & 1 & $-.812^{*}$ & $-.779^{*}$ & $-.547^{*}$ & $-.670^{*}$ & $.837^{*}$ & .111 & $.402^{* *}$ \\
\hline & Significance & & .000 & .000 & .001 & .000 & .000 & .545 & .023 \\
\hline & $N$ & 32 & 32 & 32 & 32 & 32 & 32 & 32 & 32 \\
\hline \multirow[t]{3}{*}{ TIME } & Correlation & & 1 & $.680^{*}$ & $.632^{*}$ & $.673^{*}$ & $-.716^{*}$ & -.126 & .296 \\
\hline & Significance & & & .000 & .000 & .000 & .000 & .492 & .100 \\
\hline & $N$ & & 32 & 32 & 32 & 32 & 32 & 32 & 32 \\
\hline \multirow[t]{3}{*}{ COST } & Correlation & & & 1 & $.496^{*}$ & $.474^{*}$ & $-.668^{*}$ & -.122 & $-.414^{* *}$ \\
\hline & Significance & & & 32 & .004 & .006 & .000 & .505 & .018 \\
\hline & $N$ & & & & 32 & 32 & 32 & 32 & 32 \\
\hline \multirow[t]{3}{*}{ DISP } & Correlation & & & & 1 & $.370^{* *}$ & $-.456^{*}$ & -.074 & -.171 \\
\hline & Significance & & & & & .037 & .009 & .687 & .351 \\
\hline & $N$ & & & & 32 & 32 & 32 & 32 & 32 \\
\hline \multirow[t]{3}{*}{ EMSN } & Correlation & & & & & 1 & $-.656^{*}$ & -.047 & -.192 \\
\hline & Significance & & & & & & .000 & .800 & .292 \\
\hline & $N$ & & & & & 32 & 32 & 32 & 32 \\
\hline \multirow[t]{3}{*}{ SALE } & Correlation & & & & & & 1 & .122 & $.403^{* *}$ \\
\hline & Significance & & & & & & & .507 & .022 \\
\hline & $N$ & & & & & & 32 & 32 & 32 \\
\hline \multirow[t]{3}{*}{ FLEX } & Correlation & & & & & & & 1 & .196 \\
\hline & Significance & & & & & & & & .283 \\
\hline & $N$ & & & & & & & 32 & 32 \\
\hline \multirow[t]{3}{*}{ QUAL } & Correlation & & & & & & & & 1 \\
\hline & Significance & & & & & & & & \\
\hline & $N$ & & & & & & & & 32 \\
\hline
\end{tabular}

*Correlation is significant at the 0.01 level (2-tailed); ${ }^{* *}$ Correlation is significant at the 0.05 level (2-tailed). COST production cost, DISP disposal of waste, EMSN hazardous emissions, FLEX production flexibility, INNOV technological innovativeness, QUAL production quality, SALE sales, TIME production time.

matrix (Table 4) is obtained, which explains the relationship between the dependent variables and the variate. The values (canonical variate correlation coefficients) in this matrix indicate the relative contribution of each variable (and its direction, positive or negative) in differentiating the two groups, poor innovators and good innovators, from each other.

\section{Conclusions}

In this study, a few selected manufacturers and suppliers belonging to the paper industry are examined for their status on innovativeness. According to the defined measure of technological innovativeness, manufacturers seem to be more innovative than suppliers in the industry. The authors have considered seven, most commonly used in literature, determinants of performance to investigate the effect of innovation on them. The MANOVA results in a significant difference between the overall performance of the good innovators and that of the poor innovators. The finding is well supported by the literature (Gomes et al. 2006; Loof and Heshmati 2002). The study conducted by
Gomes et al. (2006), for example, is indicative of two outcomes relevant to the present study. One, innovation aspect of performance measurement has been the least important among the Portugalis manufacturing industries out of the six dimensions identified by the authors. This justifies the need of the present study. The second outcome that the high performers have scored slightly better than the low performers on the use of innovation dimension of performance measurement, strengthens the finding of this study. Further, the DFA reveals that increased sales, reduced time and cost of production, better control over emissions and waste, and improved quality and flexibility discriminate good innovators from the poor ones. However, increase in sales, decrease in production time, and reduction in hazardous emissions emerge as more prominent outcomes of technological innovations.

Due to a small sample size, restricted to a particular region, the findings may not be generalized for other industries and regions. More valuable results are expected if process and product innovations are studied separately, added with more than two levels of innovativeness. 
Table 2 Descriptive statistics (MANOVA)

\begin{tabular}{|c|c|c|c|c|}
\hline INNO & & Mean & Standard deviation & $N$ \\
\hline \multirow[t]{3}{*}{ TIME } & 1 & 2.7857 & .89258 & 14 \\
\hline & 2 & 1.6667 & .48507 & 18 \\
\hline & Total & 2.1563 & .88388 & 32 \\
\hline \multirow[t]{3}{*}{ COST } & 1 & 3.0000 & .87706 & 14 \\
\hline & 2 & 1.9444 & .63914 & 18 \\
\hline & Total & 2.4063 & .91084 & 32 \\
\hline \multirow[t]{3}{*}{ DISP } & 1 & 2.7143 & 1.13873 & 14 \\
\hline & 2 & 2.1667 & .78591 & 18 \\
\hline & Total & 2.4063 & .97912 & 32 \\
\hline \multirow[t]{3}{*}{ EMSN } & 1 & 3.0000 & .87706 & 14 \\
\hline & 2 & 1.8333 & .61835 & 18 \\
\hline & Total & 2.3438 & .93703 & 32 \\
\hline \multirow[t]{3}{*}{ SALE } & 1 & 3.0714 & .82874 & 14 \\
\hline & 2 & 4.5556 & .51131 & 18 \\
\hline & Total & 3.9063 & .99545 & 32 \\
\hline \multirow[t]{3}{*}{ FLEX } & 1 & 3.2143 & .57893 & 14 \\
\hline & 2 & 3.5000 & .98518 & 18 \\
\hline & Total & 3.3750 & .83280 & 32 \\
\hline \multirow[t]{3}{*}{ QUAL } & 1 & 3.5714 & .64621 & 14 \\
\hline & 2 & 4.0556 & .80237 & 18 \\
\hline & Total & 3.8438 & .76662 & 32 \\
\hline
\end{tabular}

\section{Methods}

Technological innovation is defined in this paper as the set of activities through which a new or significantly improved product or process has been launched by a company to itself or to the industry during the last 3 years (OECD 2005; Nieto 2004). A structured questionnaire (Additional file 1)

\section{Table 3 Multivariate tests}

\begin{tabular}{|c|c|c|c|c|c|c|}
\hline Effect & & Value & $F$ & $\begin{array}{c}\text { Hypo } \\
\text { df }\end{array}$ & $\begin{array}{c}\text { Error } \\
\text { df }\end{array}$ & Significance \\
\hline \multirow[t]{4}{*}{ Intercept } & $\begin{array}{l}\text { Pillai's } \\
\text { trace }\end{array}$ & .993 & 523.286 & 7.0000 & 24.000 & .000 \\
\hline & $\begin{array}{l}\text { Wilk's } \\
\text { lambda }\end{array}$ & .007 & 523.286 & 7.0000 & 24.000 & .000 \\
\hline & $\begin{array}{l}\text { Hotelling's } \\
\text { trace }\end{array}$ & 152.625 & 523.286 & 7.0000 & 24.000 & .000 \\
\hline & $\begin{array}{c}\text { Roy's } \\
\text { largest root }\end{array}$ & 152.625 & 523.286 & 7.0000 & 24.000 & .000 \\
\hline \multirow[t]{4}{*}{ INNO } & $\begin{array}{l}\text { Pillai's } \\
\text { trace }\end{array}$ & .639 & 6.066 & 7.0000 & 24.000 & .000 \\
\hline & $\begin{array}{l}\text { Wilk's } \\
\text { lambda }\end{array}$ & .361 & 6.066 & 7.0000 & 24.000 & .000 \\
\hline & $\begin{array}{l}\text { Hotelling's } \\
\text { trace }\end{array}$ & 1.769 & 6.066 & 7.0000 & 24.000 & .000 \\
\hline & $\begin{array}{c}\text { Roy's } \\
\text { largest root }\end{array}$ & 1.769 & 6.066 & 7.0000 & 24.000 & .000 \\
\hline
\end{tabular}

Table 4 Structure matrix

\begin{tabular}{lccccccc}
\hline Variate & \multicolumn{7}{c}{ Variable } \\
\cline { 2 - 8 } & SALE & TIME & EMSN & COST & QUAL & DISP & FLEX \\
\hline 1 & .856 & -.623 & -.606 & -.541 & .252 & -.221 & .132 \\
\hline
\end{tabular}

has been designed (Wan et al. 2005; Sawang 2006) and administered to a sample of SMEs operating under the paper industry in a few selected districts of northern India. The companies were identified from the business directories and through personal contacts. The questionnaire was pretested on a small sample of nine companies. Later on, 143 companies were contacted using convenience sampling method for actual data collection. With a low but sufficient response rate of $27 \%, 39$ respondents filled the questionnaire. After scrutinizing and editing the received responses, 32 questionnaires were found usable for the analysis. SPSS version 13.0 of SPSS (IBM Corporation, Armonk, NY, USA) has been used to run multivariate analysis of variance (MANOVA), followed by discriminant function analysis (DFA) to obtain the results.

\section{Additional file}

Additional file 1: Structured questionnaire.

Authors' information

PF is an associate professor of Industrial Engineering at Aligarh Muslim University. $A B, A K Z$, and $I H$ are of students of Industrial Engineering at Aligarh Muslim University.

Received: 4 April 2010 Accepted: 2 March 2012

Published: 2 October 2012

\section{References}

De Jong JPJ, Vermeulen PAM (2006) Determinants of product innovation in small firms: a comparison across industries. International Small Business J 24(6):587-609

Field A (2005) Discovering Statistics using SPSS, 2nd edn. SAGE Publications, London

Fitzgerald L, Johnston R, Brignall S, Silvestro R, Voss C (1991) Performance measurement in service business. CIMA, London

Freel MS (2005) Patterns of innovation and skill in small firms. Technovation 25:123-134

Gomes CF, Yasin MM, Lisboa JV (2006) Key performance factors of manufacturing effective performance: the impact of customers and employees. The TQM Magazine 18(4):323-340

Kaplan RS, Norton DP (1992) The balanced scorecard - measures that drive performance. Harvard Business Review :71-79

Karlsson M (2009) Innovation is needed in the paper industry. http://web.abo.fi/ meddelanden/english/2009_01/2009_01_paper_industry.sht. Accessed 20 June 2009

Lin CYY, Chen MYC (2007) Does innovation lead to performance? An empirical study of SMEs in Taiwan. Management Research News 30(2):115-132

Loof H, Heshmati A (2002) Knowledge capital and performance heterogeneity: a firm level innovation study. International Journal of Production Economics 76:61-85

Mansury MA, Love JH (2008) Innovation, productivity and growth in US business services: a firm level analysis. Technovation 28:52-62

Michie J, Sheehan M (2003) Labour market deregulation, flexibility and innovation. Cambridge J of Economics 27(1):123-143 
Neely A, Gregory M, Platts K (1995) Performance measurement system design: a literature review and research agenda. International J of Operations \& Production Management 15(4):80-116

Nieto M (2004) Basic propositions for the study of the technological innovation process in the firm. European J of innovation Management 7(4):314-324

OECD (2005) Oslo manual: proposed guidelines for collecting and interpreting technological innovation data, 3rd edn. OECD Publishing, Paris

Paper industry in India (2009) http://stationery.indiabizclub.com/info/ properties_of_paper/properties_of_paper_industry_in_india. Accessed 20 June 2009

Pavitt K (1984) Sectoral patterns of technical change: towards a taxonomy and a theory. Research Policy 13:343-373

Prajogo D, Laosirihongthong T, Sohal A, Boon-itt S (2007) Manufacturing strategies and innovation performance in newly industrialized countries. Industrial Management and Data Systems 107(1):52-68

Sawang S (2006) An empirical study: a role of financial and non-financial performance measurement and perceived innovation effectiveness. Proc IEEE Int Conf on Management of Innovation and Technology 2:1063-1065

Wan D, Ong CH, Lee F (2005) Determinants of firm innovation in Singapore. Technovation 25:261-268

doi:10.1186/2251-712x-8-23

Cite this article as: Farooquie et al: An empirical study of innovationperformance linkage in the paper industry. Journal of Industrial

Engineering International 2012 8:23.

\section{Submit your manuscript to a SpringerOpen ${ }^{\circ}$ journal and benefit from:}

- Convenient online submission

- Rigorous peer review

- Immediate publication on acceptance

- Open access: articles freely available online

- High visibility within the field

- Retaining the copyright to your article

Submit your next manuscript at $>$ springeropen.com 